\title{
Chromatin Dynamics and Transcriptional Control of Circadian Rhythms in Arabidopsis
}

\author{
Aida Maric ${ }^{1}$ and Paloma Mas ${ }^{1,2, *}$ \\ 1 Centre for Research in Agricultural Genomics (CRAG), CSIC-IRTA-UAB-UB, Campus UAB, Bellaterra, \\ 08193 Barcelona, Spain; aida.maric@cragenomica.es \\ 2 Consejo Superior de Investigaciones Científicas (CSIC), 08028 Barcelona, Spain \\ * Correspondence: paloma.mas@cragenomica.es; Tel.: +34-935636600
}

Received: 10 September 2020; Accepted: 4 October 2020; Published: 6 October 2020

\begin{abstract}
Circadian rhythms pervade nearly all aspects of plant growth, physiology, and development. Generation of the rhythms relies on an endogenous timing system or circadian clock that generates 24-h oscillations in multiple rhythmic outputs. At its bases, the plant circadian function relies on dynamic interactive networks of clock components that regulate each other to generate rhythms at specific phases during the day and night. From the initial discovery more than 13 years ago of a parallelism between the oscillations in chromatin status and the transcriptional rhythms of an Arabidopsis clock gene, a number of studies have later expanded considerably our view on the circadian epigenome and transcriptome landscapes. Here, we describe the most recent identification of chromatin-related factors that are able to directly interact with Arabidopsis clock proteins to shape the transcriptional waveforms of circadian gene expression and clock outputs. We discuss how changes in chromatin marks associate with transcript initiation, elongation, and the rhythms of nascent RNAs, and speculate on future interesting research directions in the field.
\end{abstract}

Keywords: Arabidopsis; circadian clock; chromatin; transcriptional rhythms

\section{The Plant Circadian Clock}

The circadian clock is an endogenous timing mechanism able to generate biological rhythms with a period of $24 \mathrm{~h}$. Although the circadian system is daily synchronized by changes in light and temperature, it is also capable of sustaining the circadian oscillations under constant environmental conditions [1]. The circadian clock regulates an ample range of physiological, developmental and metabolic processes ensuring that they are appropriately phased in concordance with the cellular demands [2]. The mechanisms responsible for the generation of the rhythms are quite complex and involve the orchestrated expression and function of key essential components [3,4]. This molecular oscillator is exquisitely connected with synchronizing cues to timely drive the rhythms of the biological processes or rhythmic outputs controlled by the clock [5].

The circadian function is particularly important in plants, possibly due to their sessile nature and the need for constantly monitoring the environment for proper adaptation and survival. Indeed, the anticipatory function of the plant circadian system has been proposed to provide an adaptive advantage and improve fitness [6-9]. At its basis, a common mechanism responsible for the generation of rhythms in eukaryotic cells relies on circadian negative feedback loops of activators that drive the expression of negative components, which feedback to inhibit their own expression [10]. This basic transcriptional regulatory mechanism is complemented by additional layers of circadian control including among others chromatin regulation, RNA metabolism and changes in cellular and subcellular localization [11-14]. 
The molecular components of the plant circadian system have been extensively identified and characterized in the model plant Arabidopsis thaliana. Circadian studies on crops have also started to uncover the divergences but also the similarities of clock components in plant model systems and other crops [15,16]. The firstly identified Arabidopsis clock component, TIMING OF CAB EXPRESSION (TOC1) or PSEUDO RESPONSE REGULATOR1 (PRR1), was initially isolated nearly 25 years ago [17], and characterized as an evening-expressed gene, important in the regulation of circadian rhythms and flowering time [18-23]. Two additional clock components, CIRCADIAN CLOCK ASSOCIATED 1 (CCA1) and LATE ELONGATED HYPOCOTYL (LHY), were later identified and characterized [24,25]. CCA1 and LHY are two morning-expressed and partially redundant single MYB-containing proteins that form heterodimers to fulfill their circadian function [26,27]. TOC1, CCA1, and LHY were proposed to form a transcriptional feedback loop essential for circadian rhythmicity in Arabidopsis [20].

Research over the last years has contributed to extend our knowledge on the molecular circadian network, adding numerous new components and regulatory mechanisms [28]. For instance, other members of the PSEUDO RESPONSE REGULATOR (PRR) gene family including PRR3, PRR5, PRR7, and PRR9 [29,30] were found to be closely associated with the Arabidopsis clock [31,32]. The PRR gene family members are sequentially expressed, starting with PRR9 with a peak-phase closed to dawn, followed by PRR7 and PRR5 at midday and by TOC1 with a peak-phase of expression at dusk [19,29]. Other evening-expressed components include the EARLY FLOWERING 3 (ELF3) and ELF4 genes coding for two plant-specific proteins without recognizable domains [33,34] and LUX ARRHYTMO (LUX) coding for a single MYB-like GARP transcription factor [35,36]. These three clock proteins were first identified by genetic screens for components involved in flowering and hypocotyl regulation [33,37-39]. The proteins were found to interact forming a multi-protein complex called the EVENING COMPLEX (EC) $[40,41]$. Recent studies have indicated that the EC components may also have independent functions from the EC [42-44].

The main clock components engage in highly complex regulatory networks that ensure the specific phase of oscillator gene expression during the day and night (Figure 1). For instance, CCA1 and LHY repress the PRRs [45], which in turn suppress CCA1 and LHY transcription [31]. TOC1 not only represses CCA1 and $L H Y$ expression [46-48] but nearly all the oscillator genes by binding to their promoters [48]. The EC components are repressed by CCA1 and LHY in the morning [49-51] and by TOC1 in the evening [48]. In turn, the EC acts as a transcriptional repressor directly binding to the $P R R$ 9, PRR7, and LUX promoters and repressing their expression [52-55]. By repressing the repressors of CCA1 and LHY, the EC indirectly promotes CCA1 and LHY expression.

The identification of the regulatory function of the clock components uncovered a prevalent number of repressors, opening the question about the mechanisms of circadian transcriptional activation. Over the past recent years, a number of new components have been proposed to function as activators of clock gene expression (Figure 1). One example includes the LIGHT-REGULATED WD1 (LWD1) and LWD2 genes, encoding WD (Trp and Asp)-containing proteins [56]. The LWDs directly bind to the promoters of CCA1, PRR9, PRR5, and TOC1 to activate their expression [57,58]. Another example includes REVEILLE 8 (RVE8 also known as LHY-CCA1-LIKE5 or LCL5), a protein that belongs to the CCA1 and LHY single-MYB protein family [59,60]. Despite being members of the same family of plant transcription factors, RVE8 activates the expression of TOC1 and PRR5, thus, in an opposite way to the repressing function of CCA1 and LHY $[59,61]$. RVE8 also directly activates the expression of PRR9, ELF4 and LUX [62]. Other members of the RVE protein family appear to be functionally redundant with RVE8, as the rve4rve6rve8 triple mutant accentuates the long period phenotype of rve8 single mutant [62]. 


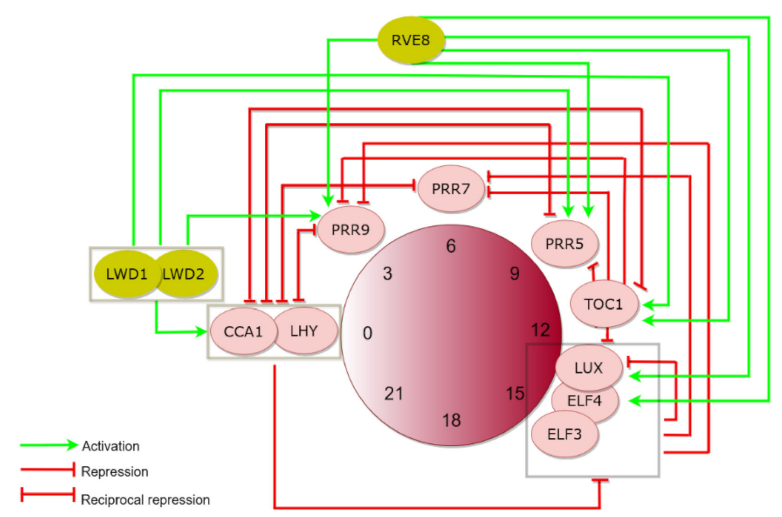

Figure 1. Schematic drawing depicting the basic regulatory network at the core of the Arabidopsis circadian oscillator. Oscillator genes are expressed at different phases during the day and night, from morning hours on the left on the central circle (clock) to evening hours on the right. Repression is depicted as red lines ending in small perpendicular dashes whereas activation is indicated by the green arrows. Clock components that interact to perform their regulatory function are encircled in grey line boxes. CCA1 and LHY are repressors of PRR genes, including TOC1. PRRs in turn repress the expression of CCA1 and LHY. Expression of Evening Complex (EC) components (LUX, ELF4, ELF3) is repressed by both CCA1/LHY and TOC1. The EC represses expression of PRR9, PRR7, and LUX. The regulatory network is dominated by repressive interactions, although recent studies have uncovered a number of activating factors such as LWD1/2 and RVE8, which activate the expression of multiple morning- and evening-expressed oscillator genes. Please consult the main text for further details.

Overall, it is well established that generation of 24-h rhythms requires the accurate coordination of the expression and activities of numerous clock components. These components regulate each other through multiple regulatory mechanisms to ultimately control plant physiology and development in synchronization with the environment [12]. In this review, we focus on one of these regulatory mechanisms: chromatin changes and its connection with circadian transcriptional regulation. We do not attempt to provide an exhaustive description of all what is known related to the topic but rather to provide an update on the most recent and relevant discoveries functionally linking chromatin status and the plant circadian clock. Readers are encouraged to consult recent reviews that have in-depth descriptions on this and other specific topics $[14,63,64]$.

\section{Transcriptional Dynamics and Chromatin Status}

Transcriptional regulation is intimately connected with chromatin status, which can be modified by changes in DNA methylation [65], histone covalent modifications [66,67], nucleosome remodeling and replacement of core histone with histone variants [68] and higher-order chromatin location and organization [69]. The four core histones (H2A, H2B, H3, and H4) can be modified at different amino acid residues by a repertoire of modifications such as acetylation, methylation, phosphorylation, ubiquitination, sumoylation, glycosylation, ADP ribosylation, biotinylation, and carbonylation [67]. These modifications are able to alter the accessibility of chromatin to the transcription machinery, thus influencing the transcriptional outcome [66].

Acetylation of histones is controlled by histone acetyltransferases (HATs) and has been mostly associated with gene activation [70]. Plants have multiple HATs [71], which have been functionally characterized to a different degree. One major class of plant HATs present homology with the yeast and Tetrahymena GCN5 (GENERAL CONTROL NONDEREPRESSIBLE 5) family [72]. GCN5 appears to be important in the regulation of many processes including cell differentiation, organogenesis, and responses to light and cold [73]. The acetylation of histones can be reverted by histone deacetylases such as RPD3 (REDUCED POTASSIUM DEPENDENCY PROTEIN 3)-like and SIR2 (SILENT INFORMATION REGULATOR PROTEIN 2)-like, which are conserved across all eukaryotes $[70,71]$. 
Histones can be also methylated by histone methyltransferases (HMTs) including a group of SET $(\mathrm{SU}(\mathrm{VAR}) / \mathrm{E}(\mathrm{Z}) / \mathrm{TRX})$ domain proteins. Histone methylation is associated either with gene activation or with repression depending on the amino acid residue of the modification [74]. For instance, histone $\mathrm{H} 3$ methylation of lysine $4(\mathrm{H} 3 \mathrm{~K} 4)$ or lysine $36(\mathrm{H} 3 \mathrm{~K} 36)$ is generally associated with activation of gene expression, whereas methylation of lysine 9 (H3K9) or lysine 27 (H3K27) is usually related to heterochromatin and gene repression [74]. Histone methylation is also reversible through the action of histone demethylases such as lysine-specific demethylase 1 (LSD1) and Jumonji $\mathrm{C}(\mathrm{JmjC})$ domain-containing proteins, which play important roles in the regulation of plant growth and development [75].

\section{Functional Link between Chromatin and Circadian Transcription}

The connection between chromatin changes and the Arabidopsis circadian clock was first reported about thirteen years ago [76]. The study showed that the rhythmic changes in TOC1 mRNA expression were associated with parallel oscillations in histone acetylation [76]. The trough of TOC1 expression coincided with histone deacetylation and with maximal CCA1 repressor binding [76]. Later studies reported that other histone marks also associate with the chromatin state at the TOC1 promoter [77,78]. The accumulation of some of these histone marks such as histone 3 lysine 4 trimethylation (H3K4me3) was found to antagonize the binding of clock repressors, ensuring that repression occurred at the proper time during the day and night cycle [78]. The rhythms in histone marks were found not only at the TOC1 promoter but in many oscillator loci [63]. From that point on, a number of chromatin-related factors were identified as "writers" and "erasers" of the histone marks important for the circadian oscillation. Here we describe the most relevant studies over the last couple of years (Table 1).

Table 1. List of the most recent findings connecting chromatin changes and circadian oscillator genes in Arabidopsis.

\begin{tabular}{llll}
\hline \multicolumn{1}{c}{ Histone Mark } & Clock/Chromatin-Related Factor & Regulated Clock Component & Reference \\
\hline Acetylation & HAF2 & PRR5, LUX & {$[79]$} \\
\hline Deacetylation & Sin3-HDAC & CCA1, PRR9 & {$[80]$} \\
& ELF3-HDA9 & TOC1 & {$[81]$} \\
& EC-HDA9-HOS15 & GI & {$[82]$} \\
& HDA6-CCA1/LHY & TOC1 & {$[83]$} \\
& HDA6-TOC1 & CCA1, LHY, other clock genes & {$[84]$} \\
\hline Methylation & SDG2 (ATXR3) & CCA1, LHY & {$[78,85]$} \\
& RVE8/LNKs & PRR5, TOC1 nascent RNAs & {$[86]$} \\
\hline Demethylation & JMJ14 & CCA1, LHY & {$[85]$} \\
& CCA1/LHY-LDL1/2 & TOC1 & {$[83]$} \\
& TOC1-LDL1/2 & CCA1, LHY, other clock genes & {$[84]$} \\
& JMJ13 & CCA1, LHY & {$[87]$} \\
\hline Monoubiquitination & HUB1/HUB2 & CCA1 & {$[88]$} \\
\hline Histone Variant H2A.Z & ELF3-SWR1 & PRR7, PRR9 & {$[89]$} \\
\hline
\end{tabular}

It is well established that increasing patterns of histone acetylation at the promoters of clock genes correlate with their rising phase of expression [63]. A recent study has provided some clues about chromatin-related factors contributing to this histone acetylation [79]. The study has shown that the expression of HAF2, a histone acetyltransferase of the TAFII250 family 2, is activated at midday, and this activation promotes histone acetylation at the PRR5 and LUX loci, coincident with their raising phase of expression [79]. If histone acetylation associates with activation, what are the chromatin-related components that facilitate the histone deacetylation during the declining phase? A number of histone deacetylases had been already identified [71]. However, a recent report has provided evidence that the evolutionarily conserved Sin3-histone deacetylase complex (HDAC) is connected with the plant clock [80]. The study showed that components of the Sin3-HDAC 
complex, SAP30 FUNCTION-RELATED 1 (AFR1), and AFR2, are circadianly-regulated. Moreover, the evening-expressed AFR proteins contribute to the repression of CCA1 and PRR 9 during the night, facilitating histone deacetylation by directly binding to their promoters. Thus, rhythmic histone deacetylation by the Sin3-HDAC complex contributes to shape the appropriate circadian waveforms of morning-expressed circadian genes [80].

Other histone deacetylases have been identified in studies of evening-expressed genes such as TOC1, which is also regulated by changing histone deacetylation patterns [81]. Indeed, HISTONE DEACETYLASE 9 (HDA9) and ELF3 directly interact and regulate the declining phase of TOC1 after dusk. This regulation relies on the direct binding of HDA9 to the TOC1 promoter through the interaction with ELF3. The EC-HDA9 complex facilitates histone deacetylation and represses TOC1 expression during the night. The components of the EC also interact with HDA9 and with HIGH EXPRESSION OF OSMOTICALLY RESPONSIVE GENE 15 (HOS15), a WD40 repeat protein at the promoter of the clock- and flowering-related gene GIGANTEA (GI), leading to histone deacetylation and transcriptional repression of GI [82]. PRR9 also interacts with a member of the plant Groucho/Tup1 corepressor family, TOPLESS/TOPLESS-RELATED (TPL/TPR) and with HDA6, defining together a repressive complex at the promoters of CCA1 and LHY [90]. The studies thus provide examples of the direct interaction between clock components and chromatin-related factors, which underscores the importance of chromatin status and regulation of circadian clock gene expression.

In addition to histone acetylation/deacetylation, other histone marks are also associated with circadian gene expression. For instance, the circadian accumulation of H3K4me3 at clock loci was proposed to be mediated by the histone methyltransferase SDG2/ATXR3 (SET DOMAIN GROUP 2/ARABIDOPSIS TRITHORAX RELATED 3) [78]. In a more recent study, Song et al. have not only verified the role of SDG2/ATXR3 controlling circadian histone methylation but also identified a role for the Jumonji C domain-containing histone demethylase (JMJ14) as regulator of circadian oscillations [85]. Notably, the study has reported a feedback between histone modifications and the diurnal regulation of circadian clock genes [85]. On one hand, the histone methyltransferase SDG2 (as a "writer") and the histone demethylase JMJ14 (as an "eraser") regulate the expression of circadian oscillator genes by modulating H3K4me3 accumulation. In turn, CCA1 and LHY were shown to regulate directly the diurnal expression of JMJ14 and indirectly that of SDG2, which leads to the rhythmic patterns of H3K4me3 accumulation in the target loci. Furthermore, a genome-wide analysis showed a limited overlap between H3K4me3 and H3K9ac marks in morning-phased and evening-phased genes, suggesting specific roles of different histone modifications controlling diurnal gene expression in Arabidopsis. Another study has recently shown that the expression of TOC1 is also repressed by histone demethylation [83]. In this case, the repression requires the coordinated interaction of CCA1/LHY with the Lysine-Specific Demethylase 1 (LSD1)-like histone demethylases, LDL1 and LDL2 [75]. LDL1 and LDL2 also interact with the histone deacetylase HDA6 providing a double mechanism for repression of TOC1 expression by both histone demethylation and deacetylation [83]. Notably, the authors have also recently shown that HDA6 and LDL1/2 can in turn interact with TOC1, and the complex contributes to the repression of CCA1, LHY, and other circadian related genes [84]. Therefore, the LDL1/2-HDA6 complex seems to play a relevant role controlling the expression of a subset of clock-related genes.

ELF3 also represses target gene expression at the end of the day by directly interacting with a protein from the chromatin-related SWI2/SNF2-RELATED (SWR1) complex [89]. The SWR1 complex associates with chromatin and catalyzes the histone variant H2A.Z exchange at genomic sites. H2A.Z is a well-conserved histone variant [91] that influences transcriptional activities of associated genes [92]. Consistently, the EC-SWR1 complex is able to bind to the PRR7 and PRR9 loci to control both the deposition of H2A.Z and the repression of these genes at dusk. The study thus provides a mechanism by which repressive chromatin domains are temporally defined by the circadian clock [89].

A majority of studies on the transcriptional circadian regulation has mainly focused on steady-state mRNA expression. A recent report however, has provided evidence on the rhythms in transcriptional synthesis, circadian nascent RNAs and chromatin modifications [86]. The study showed a modular 
function of RVE8, with its MYB domain responsible for the DNA binding, and its LCL domain providing the platform for the interaction with the clock components known as NIGHT LIGHT-INDUCIBLE AND CLOCK-REGULATED proteins (LNKs) [61,93-95]. LNKs rhythmically recruit the RNA Polymerase II and the transcript elongation FACT complex to co-occupy the promoters of the clock genes TOC1 and PRR5 [86]. The RVE8-LNKs interaction and the recruitment of the transcriptional machinery ultimately define not only transcript initiation and elongation but also the chromatin status including changes in histone marks such as H3K4me3 accumulation. Analyses of nascent RNAs by nuclear run-on transcription by bromouridine immunocapture indeed showed that the rhythmic occupancy of the transcriptional machinery results in oscillatory nascent RNAs [86].

Another recent study has provided further information on transcript elongation and pre-mRNA processing of CCA1. The study focused on histone H2B monoubiquitination (H2Bub), which in Arabidopsis is controlled by HISTONE MONOUBIQUITINATION1 (HUB1) and HUB2 E3 ubiquitin ligases together with the UBIQUITIN-CONJUGATING ENZYME 1 (UBC1) and UBC2 E2-conjugating enzymes [88]. HUB proteins interact with the previously uncharacterized RNA-binding motif-containing proteins, SPEN3 and KHD1 [88]. In the spen3-1 and hub1-4 mutants, H2Bub accumulation was reduced and $C C A 1 \alpha$ and $C C A 1 \beta$ splice isoforms were altered. The mutant plants showed short circadian period length phenotypes in agreement with the reduced expression of CCA1. Overall, the study showed that H2Bub deposition associated with CCA1 transcript elongation and pre-mRNA processing are two processes that are facilitated by the HUB1/HUB2 complex [88].

The circadian clock controls many outputs or rhythmic biological processes that occur at the most appropriate diurnal or seasonal time. Chromatin marks have been recently associated with seasonal regulation [96]. Indeed, genome-wide analyses in a natural population of perennial Arabidopsis halleri have uncovered a close connection of histone $\mathrm{H} 3$ lysine 27 trimethylation (H3K27me3) deposition with the control of seasonal gene regulation. The seasonal accumulation of H3K27me3 is phase-delayed in comparison with the H3K4me3 oscillation, most prevalently for genes associated with environmental memory. The authors thus proposed that H3K27me3 marks can control seasonal responses by monitoring past transcriptional activity for long-term regulation of expression in a subset of genes in plants grown under natural environmental conditions [96].

One fundamental clock output is the photoperiodic regulation of flowering time [97,98]. Many studies have previously shown the importance of chromatin remodeling at flowering-related loci [99]. A recent study has proposed a hierarchical graphical model inferring genome-wide gene regulatory networks connecting flower development and circadian signaling [100]. The study identified two major connecting hubs: HFR1 (LONG HYPOCOTYL IN FAR-RED) and LHY. Indeed, the network analyses showed that LHY controls a number of transcription factors directly related with flower development [100]. Notably, during the transition to flowering, LHY shows in turn a significant change in H3K4me3 at the shoot apical meristem [101]. HFR1 directly interacts with the histone acetyltransferase HAC1 (HISTONE ACETYLTRANSFERASE 1) and bind to AG (AGAMOUS, a floral development factor) to activate its expression via histone acetylation. Consistently, the authors found a flower-specific peak of H3K27ac at the $A G$ gene body closely coinciding with a HFR1 binding motif. HFR1 plays a key role in the transducing signals from light and temperature to influence circadian signaling and flowering development. It would be interesting to apply this kind of approaches with time series to further infer dynamics and new connections between chromatin changes at the core of the oscillator and in clock related outputs.

Another example connecting chromatin changes with the regulation of flowering time was recently provided by a study on the florigen gene FLOWERING LOCUS T (FT). FT shows a 24-h oscillation under long-day (LD) conditions with a peak of expression during the day. At dusk, the HISTONE DEACETYLASE 2C (HD2C) is recruited to the FT locus and deacetylates histones to repress $F T$ transcription. HD2C competes with CONSTANS (CO), the activator of $F T$, for the binding of the MORF-RELATED GENE 2 (MRG2) [102]. Thus, the study involves a histone deacetylase and histone methylation readers to shape the photoperiodic-dependent waveform of $F T$ expression. H2B 
monoubiquitination and SPEN3 function are not only important for CCA1 transcript elongation and pre-mRNA processing as mentioned above [88], but are also important in the regulation of the flowering [88]. Indeed, the spen3-1 mutant plants showed a delay in flowering time that correlated with an enhanced expression of the flowering-related gene FLOWERING LOCUS C (FLC), most likely due to an increased distal versus proximal ratio of its antisense COOLAIR transcript [88].

$F T$ is regulated by the precisely coordinated action of several players. For instance, $\mathrm{CO}$ forms a protein complex together with the B and C subunits of Nuclear Factor Y (NF-Y) to activate FT expression close to dusk. In contrast, the Polycomb repressive complex 1 (PRC1) and PRC2 proteins silence FT expression. PRC proteins show H3K27 methyltransferase activity that generates H3K27 trimethylation (H3K27me3) and maintain this mark, also facilitating other repressive marks [103]. A recent study has shown that the NF-CO complex favors a reconfiguration of the chromosomal conformation at FT resulting in reduced binding of Polycomb proteins to the FT promoter [104]. This chromatin looping and reduced binding of Polycomb proteins relieve the Polycomb-mediated silencing, resulting in FT de-repression near dusk.

Another example includes the role of histone demethylation in the regulation of flowering time. The study shows that JMJ13, which possesses H3K27me3 site-specific demethylase activity, acts as a flowering repressor, and modulates flowering time in a photoperiod- and temperature-dependent manner [87]. The study also shows that the expression of main clock genes such as LHY and CCA1 and flowering-related genes such as $C O$ was up-regulated in jmj13 mutant plants [87]. These results open the question of whether JMJ13 directly regulates clock through changes in histone demethylation at their loci. JMJ5/JMJ30 has been also connected with circadian regulation and in particular with temperature compensation [105]. However, this function appears not to involve changes in H3K36 methylation at the circadian clock loci [105].

A recent study has shown that the circadian clock regulates other outputs such as seed dormancy through the concerted action of the ATP-dependent chromatin-remodeling factor PICKLE (PKL) [106] and the EC component LUX [107]. The two proteins interact and bind to the locus of the DELAY OF GERMINATION1 (DOG1) gene, which encodes a protein involved in seed dormancy [108]. The H3K27me3 accumulation at the DOG1 locus was reduced in $p k l$ or lux mutants. The authors conclude that the circadian clock, through LUX and its interaction with PKL, modulates seed dormancy during seed development by controlling the expression of DOG1. This regulation might be important to prevent seeds from becoming overly dormant [107].

\section{Future Perspectives}

Circadian studies are rapidly expanding our view on how the circadian system works in different parts of the plant, and how mobile signals are able to synchronize clocks in distal organs [109-113]. Over the past recent years, it has become increasingly clear that circadian information is shared through short- and long-distance communication. The strength of circadian cell-to-cell coupling differs among cells and tissues [114,115]. For example, coupling is minimum among cotyledon cells [116], variable in leaves [117-119], high in roots [120] and between the vasculature and neighbor mesophyll cells [121], and very high within cells at the shoot apex [122]. Long-distance circadian synchronization on the other hand, seems to occur through shoot-to-root photosynthetic signaling [123], light piping down the root [124] and by the movement of ELF4 from shoots to regulate the period of the root clock in a temperature-dependent manner [113]. The studies highlight specific and autonomous circadian function, which urgently calls for studies on changes of the chromatin status not only with a temporal resolution (circadian or seasonal) but also with spatial definition in order to identify cell, tissue-, and organ-specific circadian chromatin landscapes.

Likewise, over recent years, chromatin conformation capture approaches have provided an unprecedented three-dimensional view of chromatin organization [125]. Studies with animal cells have uncovered a hierarchical system with compartment, domains and loops, playing important roles in the control of transcription [126]. Similar studies in plants have now shown that plant cells contain 
comparable high-order structures [69] with the notable exception of the TAD-like loop domains found in mammals or the lack of a plant CTCF-like insulator protein [126]. It would be then interesting to fully understand the functional divergences of the high-order chromatin formation and organization in plants compared to animals. Responses of plant chromatin conformation to different environmental and cellular signals would be also interesting to elucidate, focusing on the functional connection between their formation and their specific biological functions. Circadian changes on chromatin conformation and nuclear localization in different tissues and organs would be also worth exploring. We surely have ahead many interesting discoveries within the plant circadian field.

Author Contributions: A.M. and P.M. wrote and revise the review. All authors have read and agreed to the published version of the manuscript.

Funding: The Mas laboratory is funded from the FEDER/Spanish Ministry of Economy and Competitiveness (Reference: PID2019-106653GB-I00), from the Ramon Areces Foundation (Reference: V6423) and from the Generalitat de Catalunya (AGAUR) (Reference: 2017 SGR 1211). P.M. laboratory also acknowledges financial support from the CERCA Program/Generalitat de Catalunya and by the Spanish Ministry of Economy and Competitiveness through the "Severo Ochoa Program for Centres of Excellence" (Reference: (SEV-2015-0533). A.M. is a recipient of a "Severo Ochoa" FPI predoctoral scholarship from the Spanish Ministry of Economy and Competitiveness (BES-2016-076741).

Acknowledgments: We apologize to those colleagues whose work was not included here due to space constraints.

Conflicts of Interest: The authors declare no conflict of interest.

\section{References}

1. Gachon, F.; Nagoshi, E.; Brown, S.A.; Ripperger, J.; Schibler, U. The mammalian circadian timing sytem: From gene expression to physiology. Chromosoma 2004, 113, 103-112. [CrossRef] [PubMed]

2. Brown, S.A. Circadian Metabolism: From Mechanisms to Metabolomics and Medicine. Trends Endocrinol. Metab. 2016, 27, 415-426. [CrossRef] [PubMed]

3. Cox, K.H.; Takahashi, J.S. Circadian clock genes and the transcriptional architecture of the clock mechanism. J. Mol. Endocrinol. 2019, 63, R93-R102. [CrossRef] [PubMed]

4. Doherty, C.J.; Kay, S.A. Circadian surprise-It's not all about transcription. Science 2012, 338, 338-400. [CrossRef] [PubMed]

5. Young, M.W.; Kay, S.A. Time zones: A comparative genetics of circadian clocks. Nat. Rev. Gen. 2001, 2, 702-715. [CrossRef] [PubMed]

6. Green, R.M.; Tingay, S.; Wang, Z.Y.; Tobin, E.M. Circadian rhythms confer a higher level of fitness to Arabidopsis plants. Plant Physiol. 2002, 129, 576-584. [CrossRef] [PubMed]

7. Resco, V.; Hartwell, J.; Hall, A. Ecological implications of plants ability to tell the time. Ecol. Lett. 2009, 12, 583-592. [CrossRef] [PubMed]

8. Yerushalmi, S.; Green, R.M. Evidence for the adaptive significance of circadian rhythms. Ecol. Lett. 2009, 12, 970-981. [CrossRef] [PubMed]

9. Dodd, A.N.; Salathia, N.; Hall, A.; Kevei, E.; Toth, R.; Nagy, F.; Hibberd, J.M.; Millar, A.J.; Webb, A.A. Plant circadian clocks increase photosynthesis, growth, survival, and competitive advantage. Science 2005, 309, 630-633. [CrossRef] [PubMed]

10. Sanchez, S.E.; Kay, S.A. The Plant Circadian Clock: From a Simple Timekeeper to a Complex Developmental Manager. Cold Spring Harb. Perspect. Biol. 2016, 8, a027748. [CrossRef] [PubMed]

11. Más, P. Circadian clock function in Arabidopsis thaliana: Time beyond transcription. Trends Cell Biol. 2008, 18, 273-281. [CrossRef] [PubMed]

12. Seo, P.J.; Mas, P. Multiple layers of posttranslational regulation refine circadian clock activity in Arabidopsis. Plant Cell. 2014, 26, 79-87. [CrossRef] [PubMed]

13. Mateos, J.L.; de Leone, M.J.; Torchio, J.; Reichel, M.; Staiger, D. Beyond transcription: Fine-tuning of circadian timekeeping by post-transcriptional regulation. Genes 2018, 9, 616. [CrossRef] [PubMed]

14. Yang, P.; Wang, J.; Huang, F.Y.; Yang, S.; Wu, K. The plant circadian clock and chromatin modifications. Genes 2018, 9, 561. [CrossRef] [PubMed]

15. Bendix, C.; Marshall, C.M.; Harmon, F.G. Circadian Clock Genes Universally Control Key Agricultural Traits. Mol. Plant 2015, 8, 1135-1152. [CrossRef] [PubMed] 
16. McClung, C.R. Beyond Arabidopsis: The circadian clock in non-model plant species. Semin. Cell Dev. Biol. 2013, 24, 430-436. [CrossRef]

17. Millar, A.J.; Carré, I.A.; Strayer, C.A.; Chua, N.H.; Kay, S.A. Circadian clock mutants in Arabidopsis identified by luciferase imaging. Science 1995, 267, 1161-1163. [CrossRef]

18. DSomers, E.; Webb, A.A.R.; Pearson, M.; Kay, S.A. The short-period mutant toc1-1, alters circadian clock regulation of multiple outputs throughout development in Arabidopsis thaliana. Development 1998, 125, $485-494$.

19. Strayer, C.; Oyama, T.; Schultz, T.F.; Raman, R.; Somers, D.E.; Mas, P.; Panda, S.; Kreps, J.A.; Kay, S.A. Cloning of the Arabidopsis clock gene TOC1, an autoregulatory response regulator homolog. Science 2000, 289, 768-771. [CrossRef]

20. Alabadí, D.; Oyama, T.; Yanovsky, M.J.; Harmon, F.G.; Más, P.; Kay, S.A. Reciprocal regulation between TOC1 and LHY/CCA1 within the Arabidopsis circadian clock. Science 2001, 293, 880-883. [CrossRef]

21. Más, P.; Alabadí, D.; Yanovsky, M.J.; Oyama, T.; Kay, S.A. Dual role of TOC1 in the control of circadian and photomorphogenic responses in Arabidopsis. Plant Cell 2003, 15, 223-236. [CrossRef] [PubMed]

22. Más, P.; Kim, W.-Y.; Somers, D.E.; Kay, S.A. Targeted degradation of TOC1 by ZTL modulates circadian function in Arabidopsis thaliana. Nature 2003, 426, 567-570. [CrossRef] [PubMed]

23. Mizuno, T.; Nakamichi, N. Pseudo-Response regulators (PRRs) or true oscillator components (TOCs). Plant Cell Physiol. 2005, 46, 677-685. [CrossRef] [PubMed]

24. Wang, Z.Y.; Tobin, E.M. Constitutive expression of the CIRCADIAN CLOCK ASSOCIATED 1 (CCA1) gene disrupts circadian rhythms and suppresses its own expression. Cell 1998, 93, 1207-1217. [CrossRef]

25. Schaffer, R.; Ramsay, N.; Samach, A.; Corden, S.; Putterill, J.; Carré, I.A.; Coupland, G. The late elongated hypocotyl mutation of Arabidopsis disrupts circadian rhythms and the photoperiodic control of flowering. Cell 1998, 93, 1219-1229. [CrossRef]

26. Lu, S.X.; Knowles, S.M.; Andronis, C.; Ong, M.S.; Tobin, E.M. CIRCADIAN CLOCK ASSOCIATED 1 and LATE ELONGATED HYPOCOTYL function synergistically in the circadian clock of Arabidopsis. Plant Physiol. 2009, 150, 834-843. [CrossRef]

27. Mizoguchi, T.; Wheatley, K.; Hanzawa, Y.; Wright, L.; Mizoguchi, M.; Song, H.R.; Carre, I.A.; Coupland, G. LHY and CCA1 are partially redundant genes required to maintain circadian rhythms in Arabidopsis. Dev. Cell 2002, 2, 629-641. [CrossRef]

28. Nohales, M.A.; Kay, S.A. Molecular mechanisms at the core of the plant circadian oscillator. Nat. Struct. Mol. Biol. 2016, 23, 1061-1069. [CrossRef]

29. Matsushika, A.; Makino, S.; Kojima, M.; Mizuno, T. Circadian waves of expression of the APRR1/TOC1 family of pseudo-response regulators in Arabidopsis thaliana: Insight into the plant circadian clock. Plant Cell Physiol. 2000, 41, 1002-1012. [CrossRef]

30. Makino, S.; Kiba, T.; Imamura, A.; Hanaki, N.; Nakamura, A.; Suzuki, T.; Taniguchi, M.; Ueguchi, C.; Sugiyama, T.; Mizuno, T. Genes encoding pseudo-response regulators: Insight into His-to-Asp phosphorelay and circadian rhythm in Arabidopsis thaliana. Plant Cell Physiol. 2000, 41, 791-803. [CrossRef]

31. Nakamichi, N.; Kita, M.; Ito, S.; Yamashino, T.; Mizuno, T. PSEUDO-RESPONSE REGULATORS, PRR9, PRR7 and PRR5, together play essential roles close to the circadian clock of Arabidopsis thaliana. Plant Cell Physiol. 2005, 46, 686-698. [CrossRef] [PubMed]

32. Adams, S.; Manfield, I.; Stockley, P.; Carré, I.A. Revised Morning Loops of the Arabidopsis Circadian Clock Based on Analyses of Direct Regulatory Interactions. PLoS ONE 2015, 10, e0143943. [CrossRef] [PubMed]

33. Hicks, K.A.; Albertson, T.M.; Wagner, D.R. EARLY FLOWERING3 Encodes a Novel Protein That Regulates Circadian Clock Function and Flowering in Arabidopsis. Plant Cell 2001, 13, 1281-1292. [CrossRef] [PubMed]

34. Doyle, M.R.; Davis, S.J.; Bastow, R.M.; McWatters, H.G.; Kozma-Bognár, L.; Nagy, F.; Millar, A.J. The ELF4 gene controls circadian rhythms and flowering time in Arabidopsis thaliana. Nature 2002, 419, 74-77. [CrossRef]

35. Hazen, S.P.; Schultz, T.F.; Pruneda-Paz, J.L.; Borevitz, J.O.; Ecker, J.R.; Kay, S.A. LUX ARRHYTHMO encodes a Myb domain protein essential for circadian rhythms. Proc. Natl. Acad. Sci. USA 2005, 102, 10387-10392. [CrossRef]

36. Onai, K.; Ishiura, M. PHYTOCLOCK 1 encoding a novel GARP protein essential for the Arabidopsis circadian clock. Genes Cells 2005, 10, 963-972. [CrossRef] 
37. McWatters, H.G.; Kolmos, E.; Hall, A.; Doyle, M.R.; Amasino, R.M.; Gyula, P.; Nagy, F.; Millar, A.J.; Davis, S.J. ELF4 is required for oscillatory properties of the circadian clock. Plant Physiol. 2007, 144, 391-401. [CrossRef]

38. Kolmos, E.; Nowak, M.; Werner, M.; Fischer, K.; Schwarz, G.; Mathews, S.; Schoof, H.; Nagy, F.; Bujnicki, J.M.; Davis, S.J. Integrating ELF4 into the circadian system through combined structural and functional studies. HFSP J. 2009, 3, 350-366. [CrossRef]

39. McWatters, H.G.; Bastow, R.M.; Hall, A.; Millar, A.J. The ELF3 zeitnehmer regulates light signalling to the circadian clock. Nature 2000, 408, 716-720. [CrossRef]

40. Nusinow, D.A.; Helfer, A.; Hamilton, E.E.; King, J.J.; Imaizumi, T.; Schultz, T.F.; Farre, E.M.; Kay, S.A. The ELF4-ELF3-LUX complex links the circadian clock to diurnal control of hypocotyl growth. Nature 2011, 475, 398-402. [CrossRef]

41. Herrero, E.; Kolmos, E.; Bujdoso, N.; Yuan, Y.; Wang, M.; Berns, M.C.; Uhlworm, H.; Coupland, G.; Saini, R.; Jaskolski, M.; et al. EARLY FLOWERING4 recruitment of EARLY FLOWERING3 in the nucleus sustains the Arabidopsis circadian clock. Plant Cell 2012, 24, 428-443. [CrossRef] [PubMed]

42. Ezer, D.; Jung, J.H.; Lan, H.; Biswas, S.; Gregoire, L.; Box, M.S.; Charoensawan, V.; Cortijo, S.; Lai, X.; Stockle, D.; et al. The evening complex coordinates environmental and endogenous signals in Arabidopsis. Nat. Plants 2017, 3, 17087. [CrossRef] [PubMed]

43. Kim, Y.; Lim, J.; Yeom, M.; Kim, H.; Kim, J.; Wang, L.; Kim, W.Y.; Somers, D.E.; Nam, H.G. ELF4 Regulates GIGANTEA Chromatin Access through Subnuclear Sequestration. Cell Rep. 2013, 3, 671-677. [CrossRef] [PubMed]

44. Nieto, C.; López-Salmerón, V.; Davière, J.-M.; Prat, S. ELF3-PIF4 Interaction Regulates Plant Growth Independently of the Evening Complex. Curr. Biol. 2015, 25, 187-193. [CrossRef] [PubMed]

45. Kamioka, M.; Takao, S.; Suzuki, T.; Taki, K.; Higashiyam, T.; Kinoshita, T.; Nakamichi, N. Direct repression of evening genes by CIRCADIAN CLOCK-ASSOCIATED1 in the Arabidopsis circadian clock. Plant Cell 2016, 28, 696-711. [CrossRef]

46. Pokhilko, A.; Fernandez, A.P.; Edwards, K.D.; Southern, M.M.; Halliday, K.J.; Millar, A.J. The clock gene circuit in Arabidopsis includes a repressilator with additional feedback loops. Mol. Syst. Biol. 2012, 8, 574. [CrossRef]

47. Gendron, J.M.; Pruneda-Paz, J.L.; Doherty, C.J.; Gross, A.M.; Kang, S.E.; Kay, S.A. Arabidopsis circadian clock protein, TOC1,is a DNA-binding transcription factor. Proc. Natl. Acad. Sci. USA 2012, 109, 3167-3172. [CrossRef]

48. Huang, W.; Pérez-García, P.; Pokhilko, A.; Millar, A.J.; Antoshechkin, I.; Riechmann, J.L.; Mas, P. Mapping the core of the Arabidopsis circadian clock defines the network structure of the oscillator. Science 2012, 335, 75-79. [CrossRef]

49. Portolés, S.; Más, P. The functional interplay between protein kinase CK2 and cca1 transcriptional activity is essential for clock temperature compensation in Arabidopsis. PLoS Genet. 2010, 6, e1001201. [CrossRef]

50. Li, G.; Siddiqui, H.; Teng, Y.; Lin, R.; Wan, X.; Li, J.; Lau, O.-S.; Ouyang, X.; Dai, M.; Wan, J.; et al. Coordinated transcriptional regulation underlying the circadian clock in Arabidopsis. Nat. Cell Biol. 2011, 13, 616-622. [CrossRef]

51. SLu, X.; Webb, C.J.; Knowles, S.M.; Kim, S.H.J.; Wang, Z.; Tobin, E.M. CCA1 and ELF3 Interact in the Control of Hypocotyl Length and Flowering Time in Arabidopsis. Plant Physiol. 2012, 158, 1079-1088.

52. Dixon, L.E.; Knox, K.; Kozma-Bognar, L.; Southern, M.M.; Pokhilko, A.; Millar, A.J. Temporal Repression of Core Circadian Genes Is Mediated through EARLY FLOWERING 3 in Arabidopsis. Curr. Biol. 2011, 21, 120-125. [CrossRef] [PubMed]

53. Helfer, A.; Nusinow, D.A.; Chow, B.Y.; Gehrke, A.R.; Bulyk, M.L.; Kay, S.A. LUX ARRHYTHMO encodes a nighttime repressor of circadian gene expression in the Arabidopsis core clock. Curr. Biol. 2011, 21, 126-133. [CrossRef] [PubMed]

54. Chow, B.Y.; Helfer, A.; Nusinow, D.A.; Kay, S.A. ELF3 recruitment to the PRR9 promoter requires other Evening Complex members in the Arabidopsis circadian clock. Plant Signal Behav. 2012, 7, 170-173. [CrossRef]

55. Mizuno, T.; Nomoto, Y.; Oka, H.; Kitayama, M.; Takeuchi, A.; Tsubouchi, M.; Yamashino, T. Ambient temperature signal feeds into the circadian clock transcriptional circuitry through the EC night-time repressor in arabidopsis thaliana. Plant Cell Physiol. 2014, 55, 958-976. [CrossRef] 
56. Wu, J.F.; Wang, Y.; Wu, S.H. Two new clock proteins, LWD1 and LWD2, regulate arabidopsis photoperiodic flowering. Plant Physiol. 2008, 148, 948-959. [CrossRef]

57. Wang, Y.; Wu, J.F.; Nakamichi, N.; Sakakibara, H.; Nam, H.G.; Wu, S.H. LIGHT-REGULATED WD1 and PSEUDO-RESPONSE REGULATOR9 Form a positive feedback regulatory loop in the Arabidopsis circadian clock. Plant Cell. 2011, 23, 486-498. [CrossRef]

58. Wu, J.F.; Tsai, H.L.; Joanito, I.; Wu, Y.C.; Chang, C.W.; Li, Y.H.; Wang, Y.; Hong, J.C.; Chu, J.W.; Hsu, C.P.; et al. LWD-TCP complex activates the morning gene CCA1 in Arabidopsis. Nat. Commun. 2016, 7, 13181. [CrossRef]

59. Farinas, B.; Mas, P. Functional implication of the MYB transcription factor RVE8/LCL5 in the circadian control of histone acetylation. Plant J. 2011, 66, 318-329. [CrossRef]

60. Rawat, R.; Takahashi, N.; Hsu, P.Y.; Jones, M.A.; Schwartz, J.; Salemi, M.R.; Phinney, B.S.; Harmer, S.L. REVEILLE8 and PSEUDO-REPONSE REGULATOR5 form a negative feedback loop within the arabidopsis circadian clock. PLoS Genet. 2011, 7, e1001350. [CrossRef]

61. Xie, Q.; Wang, P.; Liu, X.; Yuan, L.; Wang, L.; Zhang, C.; Li, Y.; Xing, H.; Zhi, L.; Yue, Z.; et al. LNK1 and LNK2 Are Transcriptional Coactivators in the Arabidopsis Circadian Oscillator. Plant Cell Online 2014, 26, 2843-2857. [CrossRef] [PubMed]

62. Hsu, P.Y.; Devisetty, U.K.; Harmer, S.L. Accurate timekeeping is controlled by a cycling activator in Arabidopsis. Elife 2013, 2013. [CrossRef] [PubMed]

63. Chen, Z.J.; Mas, P. Interactive roles of chromatin regulation and circadian clock function in plants. Genome Biol. 2019, 20, 62. [CrossRef] [PubMed]

64. Davis, S.J.; Ronald, J. Making the clock tick: The transcriptional landscape of the plant circadian clock. F1000Research 2017, 6. [CrossRef]

65. Zhang, H.; Lang, Z.; Zhu, J.K. Dynamics and function of DNA methylation in plants. Nat. Rev. Mol. Cell Biol. 2018, 19, 489-506. [CrossRef]

66. Pfluger, J.; Wagner, D. Histone modifications and dynamic regulation of genome accessibility in plants. Curr. Opin. Plant Biol. 2007, 10, 645-652. [CrossRef]

67. Pikaard, C.S.; Scheid, O.M. Epigenetic regulation in plants. Cold Spring Harb. Perspect. Biol. $2014,6$. [CrossRef]

68. Probst, A.V.; Desvoyes, B.; Gutierrez, C. Similar yet critically different: The distribution, dynamics and function of histone variants. J. Exp. Bot. 2020, 71, 5191-5204. [CrossRef]

69. Dong, P.; Tu, X.; Liang, Z.; Kang, B.-H.; Zhong, S. Plant and animal chromatin three-dimensional organization: Similar structures but different functions. J. Exp. Bot. 2020, 71, 5119-5128. [CrossRef]

70. Chen, Z.J.; Tian, L. Roles of dynamic and reversible histone acetylation in plant development and polyploidy. Biochim. Biophys. Acta 2007, 1769, 295-307. [CrossRef]

71. Pandey, R.; Müller, A.; Napoli, C.A.; Selinger, D.A.; Pikaard, C.S.; Richards, E.J.; Bender, J.; Mount, D.W.; Jorgensen, R.A. Analysis of histone acetyltransferase and histone deacetylase families of Arabidopsis thaliana suggests functional diversification of chromatin modification among multicellular eukaryotes. Nucleic Acids Res. 2002, 30, 5036-5055. [CrossRef] [PubMed]

72. Brownell, J.E.; Zhou, J.; Ranalli, T.; Kobayashi, R.; Edmondson, D.G.; Roth, S.Y.; Allis, C.D. Tetrahymena histone acetyltransferase A: A homolog to yeast Gcn5p linking histone acetylation to gene activation. Cell 1996, 84, 843-851. [CrossRef]

73. Servet, C.; Silva, N.C.E.; Zhou, D.X. Histone acetyltransferase AtGCN5/HAG1 is a versatile regulator of developmental and inducible gene expression in arabidopsis. Mol. Plant 2010, 3, 670-677. [CrossRef] [PubMed]

74. Liu, C.; Lu, F.; Cui, X.; Cao, X. Histone methylation in higher plants. Annu. Rev. Plant Biol. 2010, 61, 395-420. [CrossRef] [PubMed]

75. Prakash, S.; Singh, R.; Lodhi, N. Histone demethylases and control of gene expression in plants. Cell. Mol. Biol. 2014, 60, 97-105.

76. Perales, M.; Más, P. A functional link between rhythmic changes in chromatin structure and the Arabidopsis biological clock. Plant Cell 2007, 19, 2111-2123. [CrossRef]

77. Song, H.R.; Noh, Y.S. Rhythmic Oscillation of Histone Acetylation and Methylation at the Arabidopsis Central Clock Loci. Mol. Cells 2012, 34, 279-287. [CrossRef] 
78. Malapeira, J.; Khaitova, L.C.; Mas, P. Ordered changes in histone modifications at the core of the Arabidopsis circadian clock. Proc. Natl. Acad. Sci. USA 2012, 109, 21540-21545. [CrossRef]

79. Lee, K.; Seo, P.J. The HAF2 protein shapes histone acetylation levels of PRR5 and LUX loci in Arabidopsis. Planta 2018, 248, 513-518. [CrossRef]

80. Lee, H.G.; Hong, C.; Seo, P.J. The Arabidopsis sin3-hdac complex facilitates temporal histone deacetylation at the Cca1 and Prr9 loci for robust circadian oscillation. Front. Plant Sci. 2019, 10, 171. [CrossRef]

81. Lee, K.; Mas, P.; Seo, P.J. The EC-HDA9 complex rhythmically regulates histone acetylation at the TOC1 promoter in Arabidopsis. Commun. Biol. 2019, 2, 143. [CrossRef] [PubMed]

82. Park, H.J.; Baek, D.; Cha, J.Y.; Liao, X.; Kang, S.H.; McClung, C.R.; Lee, S.Y.; Yun, D.J.; Kim, W.Y. Hos15 interacts with the histone deacetylase hda9 and the evening complex to epigenetically regulate the floral activator gigantea. Plant Cell 2019, 31,37-51. [CrossRef] [PubMed]

83. Hung, F.-Y.; Chen, F.-F.; Li, C.; Chen, C.; Lai, Y.-C.; Chen, J.-H.; Cui, Y.; Wu, K. The Arabidopsis LDL1/2-HDA6 histone modification complex is functionally associated with CCA1/LHY in regulation of circadian clock genes. Nucleic Acids Res. 2018, 46, 10669-10681. [CrossRef] [PubMed]

84. Hung, F.Y.; Chen, F.F.; Li, C.; Chen, C.; Chen, J.H.; Cui, Y.; Wu, K. The LDL1/2-HDA6 histone modification complex interacts with TOC 1 and regulates the core circadian clock components in Arabidopsis. Front. Plant Sci. 2019, 10, 233. [CrossRef]

85. Song, Q.; Huang, T.-Y.; Yu, H.H.; Ando, A.; Mas, P.; Ha, M.; Chen, Z.J. Diurnal regulation of SDG2 and JMJ14 by circadian clock oscillators orchestrates histone modification rhythms in Arabidopsis. Genome Biol. 2019, 20, 170. [CrossRef]

86. Ma, Y.; Gil, S.; Grasser, K.D.; Mas, P. Targeted recruitment of the basal transcriptional machinery by LNK clock components controls the circadian rhythms of nascent RNAs in arabidopsis. Plant Cell 2018, 30, 907-924. [CrossRef]

87. Zheng, S.; Hu, H.; Ren, H.; Yang, Z.; Qiu, Q.; Qi, W.; Liu, X.; Chen, X.; Cui, X.; Li, S.; et al. The Arabidopsis H3K27me3 demethylase JUMONJI 13 is a temperature and photoperiod dependent flowering repressor. Nat. Commun. 2019, 10, 1303. [CrossRef]

88. Woloszynska, M.; le Gall, S.; Neyt, P.; Boccardi, T.M.; Grasser, M.; Längst, G.; Aesaert, S.; Coussens, G.; Dhondt, S.; van de Slijke, E.; et al. Histone 2B monoubiquitination complex integrates transcript elongation with RNA processing at circadian clock and flowering regulators. Proc. Natl. Acad. Sci. USA 2019, 116, 8060-8069. [CrossRef]

89. Tong, M.; Lee, K.; Ezer, D.; Cortijo, S.; Jung, J.; Charoensawan, V.; Box, M.S.; Jaeger, K.E.; Takahashi, N.; Mas, P.; et al. The evening complex establishes repressive chromatin domains via H2A.Z deposition. Plant Physiol. 2020, 182, 612-625. [CrossRef]

90. Wang, L.; Kim, J.; Somers, D.E. Transcriptional corepressor TOPLESS complexes with pseudoresponse regulator proteins and histone deacetylases to regulate circadian transcription. Proc Natl Acad Sci USA 2013, 110, 761-766. [CrossRef]

91. Raisner, R.M.; Madhani, H.D. Patterning chromatin: Form and function for H2A.Z variant nucleosomes. Curr. Opin. Genet. Dev. 2006, 16, 119-124. [CrossRef] [PubMed]

92. 92. Raisner, R.M.; Hartley, P.D.; Meneghini, M.D.; Bao, M.Z.; Liu, C.L.; Schreiber, S.L.; Rando, O.J.; Madhani, H.D. Histone variant H2A.Z marks the 5' ends of both active and inactive genes in euchromatin. Cell 2005, 123, 233-248. [CrossRef] [PubMed]

93. Rugnone, M.L.; Soverna, A.F.; Sanchez, S.E.; Schlaen, R.G.; Hernando, C.E.; Seymour, D.K.; Mancini, E.; Chernomoretz, A.; Weigel, D.; Mas, P.; et al. LNK genes integrate light and clock signaling networks at the core of the Arabidopsis oscillator. Proc. Natl. Acad. Sci. USA 2013, 110, 12120-12125. [CrossRef] [PubMed]

94. Pérez-García, P.; Ma, Y.; Yanovsky, M.J.; Mas, P. Time-dependent sequestration of RVE8 by LNK proteins shapes the diurnal oscillation of anthocyanin biosynthesis. Proc. Natl. Acad. Sci. USA 2015, 112, 5249-5253. [CrossRef] [PubMed]

95. Mizuno, T.; Takeuchi, A.; Nomoto, Y.; Nakamichi, N.; Yamashino, T. The LNK1 night light-inducible and clock-regulated gene is induced also in response to warm-night through the circadian clock nighttime repressor in Arabidopsis thaliana. Plant Signal. Behav. 2014, 9, e28505. [CrossRef] [PubMed]

96. Nishio, H.; Nagano, A.J.; Ito, T.; Suzuki, Y.; Kudoh, H. Seasonal plasticity and diel stability of H3K27me3 in natural fluctuating environments. Nat. Plants 2020, 1091-1097. [CrossRef] 
97. Andrés, F.; Coupland, G. The genetic basis of flowering responses to seasonal cues. Nat. Rev. Genet. 2012, 13, 627-639. [CrossRef]

98. Johansson, M.; Staiger, D. Time to flower: Interplay between photoperiod and the circadian clock. J. Exp. Bot. 2015, 66, 719-730. [CrossRef]

99. Baulcombe, D.C.; Dean, C. Epigenetic regulation in plant responses to the environment. Cold Spring Harb. Perspect. Biol. 2014, 6, a019471. [CrossRef]

100. Duren, Z.; Wang, Y.; Wang, J.; Zhao, X.-M.; Lv, L.; Li, X.; Liu, J.; Zhu, X.-G.; Chen, L.; Wang, Y. Hierarchical graphical model reveals HFR1 bridging circadian rhythm and flower development in Arabidopsis thaliana. NPJ Syst. Biol. Appl. 2019, 5, 28. [CrossRef]

101. You, Y.; Sawikowska, A.; Neumann, M.; Posé, D.; Capovilla, G.; Langenecker, T.; Neher, R.A.; Krajewski, P.; Schmid, M. Temporal dynamics of gene expression and histone marks at the Arabidopsis shoot meristem during flowering. Nat. Commun. 2017, 8, 15120. [CrossRef] [PubMed]

102. Guo, Z.; Li, Z.; Liu, Y.; An, Z.; Peng, M.; Shen, W.H.; Dong, A.; Yu, Y. MRG1/2 histone methylation readers and $\mathrm{HD} 2 \mathrm{C}$ histone deacetylase associate in repression of the florigen gene FT to set a proper flowering time in response to day-length changes. New Phytol. 2020, 227, 1453-1466. [CrossRef] [PubMed]

103. Xiao, J.; Wagner, D. Polycomb repression in the regulation of growth and development in Arabidopsis. Curr. Opin. Plant Biol. 2015, 23, 15-24. [CrossRef] [PubMed]

104. Luo, X.; Gao, Z.; Wang, Y.; Chen, Z.; Zhang, W.; Huang, J.; Yu, H.; He, Y. The NUCLEAR FACTOR-CONSTANS complex antagonizes Polycomb repression to de-repress FLOWERING LOCUS T expression in response to inductive long days in Arabidopsis. Plant J. 2018, 95, 17-29. [CrossRef]

105. Jones, M.A.; Morohashi, K.; Grotewold, E.; Harmer, S.L. Arabidopsis JMJD5/JMJ30 Acts Independently of LUX ARRHYTHMO Within the Plant Circadian Clock to Enable Temperature Compensation. Front. Plant Sci. 2019, 10, 57. [CrossRef]

106. Suzuki, M.; McCarty, D.R. Functional symmetry of the B3 network controlling seed development. Curr. Opin. Plant Biol. 2008, 11, 548-553. [CrossRef]

107. Zha, P.; Liu, S.; Li, Y.; Ma, T.; Yang, L.; Jing, Y.; Lin, R. The Evening Complex and the Chromatin-Remodeling Factor PICKLE Coordinately Control Seed Dormancy by Directly Repressing DOG1 in Arabidopsis. Plant Commun. 2020, 1, 100011. [CrossRef]

108. Nonogaki, H. The Long-Standing Paradox of Seed Dormancy Unfolded? Trends Plant Sci. 2019, 24, 989-998. [CrossRef]

109. Sai, J.; Johnson, C.H. Different circadian oscillators control $\mathrm{Ca}(2+)$ fluxes and lhcb gene expression. Proc. Natl. Acad. Sci. USA 1999, 96, 11659-11663. [CrossRef]

110. Thain, S.C.; Murtas, G.; Lynn, J.R.; McGrath, R.B.; Millar, A.J. The circadian clock that controls gene expression in Arabidopsis is tissue specific. Plant Physiol. 2002, 130, 102-110. [CrossRef]

111. Michael, T.P.; Salome, P.A.; McClung, C.R. Two Arabidopsis circadian oscillators can be distinguished by differential temperature sensitivity. Proc. Natl. Acad. Sci. USA 2003, 100, 6878-6883. [CrossRef] [PubMed]

112. Muranaka, T.; Oyama, T. Heterogeneity of cellular circadian clocks in intact plants and its correction under light-dark cycles. Sci. Adv. 2016, 2, e1600500. [CrossRef] [PubMed]

113. Chen, W.W.; Takahashi, N.; Hirata, Y.; Ronald, J.; Porco, S.; Davis, S.J.; Nusinow, D.A.; Kay, S.A.; Mas, P. Amobile ELF4 delivers circadian temperature information from shoots to roots. Nat. Plants 2020, 6, 416-426. [CrossRef] [PubMed]

114. Yakir, E.; Hassidim, M.; Melamed-Book, N.; Hilman, D.; Kron, I.; Green, R.M. Cell autonomous and cell-type specific circadian rhythms in Arabidopsis. Plant J. 2011, 68, 520-531. [CrossRef] [PubMed]

115. Fukuda, H.; Ukai, K.; Oyama, T. Self-arrangement of cellular circadian rhythms through phase-resetting in plant roots. Phys. Rev. E 2012, 86, 41917. [CrossRef] [PubMed]

116. Thain, S.C.; Hall, A.; Millar, A.J. Functional independence of circadian clocks that regulate plant gene expression. Curr. Biol. 2000, 10, 951-956. [CrossRef]

117. Fukuda, H.; Nakamichi, N.; Hisatsune, M.; Murase, H.; Mizuno, T. Synchronization of plant circadian oscillators with a phase delay effect of the vein network. Phys. Rev. Lett. 2007, 99, 98102. [CrossRef]

118. Wenden, B.; Toner, D.L.K.; Hodge, S.K.; Grima, R.; Millar, A.J. Spontaneous spatiotemporal waves of gene expression from biological clocks in the leaf. Proc. Natl. Acad. Sci. USA 2012, 109, 6757-6762. [CrossRef]

119. Greenwood, M.; Domijan, M.; Gould, P.D.; Hall, A.J.W.; Locke, J.C.W. Coordinated circadian timing through the integration of local inputs in Arabidopsis thaliana. PLOS Biol. 2019, 17, e3000407. [CrossRef] 
120. Gould, P.D.; Domijan, M.; Greenwood, M.; Tokuda, I.T.; Rees, H.; Kozma-Bognar, L.; Hall, A.J.; Locke, J.C. Coordination of robust single cell rhythms in the Arabidopsis circadian clock via spatial waves of gene expression. Elife 2018, 7, e31700. [CrossRef]

121. Endo, M.; Shimizu, H.; Nohales, M.A.; Araki, T.; Kay, S.A. Tissue-specific clocks in Arabidopsis show asymmetric coupling. Nature 2014, 515, 419-422. [CrossRef] [PubMed]

122. Takahashi, N.; Hirata, Y.; Aihara, K.; Mas, P. A Hierarchical Multi-oscillator Network Orchestrates the Arabidopsis Circadian System. Cell 2015, 163, 148-159. [CrossRef] [PubMed]

123. James, A.B.; Monreal, J.A.; Nimmo, G.A.; Kelly, C.L.; Herzyk, P.; Jenkins, G.I.; Nimmo, H.G. The circadian clock in Arabidopsis roots is a simplified slave version of the clock in shoots. Science 2008, 322, 1832-1835. [CrossRef] [PubMed]

124. Nimmo, H.G. Entrainment of Arabidopsis roots to the light:dark cycle by light piping. Plant Cell Environ. 2018, 41, 1742-1748. [CrossRef]

125. Denker, A.; de Laat, W. The second decade of $3 \mathrm{C}$ technologies: Detailed insights into nuclear organization. Genes Dev. 2016, 30, 1357-1382. [CrossRef]

126. Yu, M.; Ren, B. The three-dimensional organization of mammalian genomes. Annu. Rev. Cell Dev. Biol. 2017, 33, 265-289. [CrossRef]

(C) 2020 by the authors. Licensee MDPI, Basel, Switzerland. This article is an open access article distributed under the terms and conditions of the Creative Commons Attribution (CC BY) license (http://creativecommons.org/licenses/by/4.0/). 